\title{
Growth and Nutrition of Mollicute-Infected Maize
}

\author{
Elizabeth de Oliveira, Paulo C. Magalhães, Reinaldo L. Gomide, Carlos A. Vasconcelos, Isabel R. P. Souza, \\ Charles M. Oliveira, Ivan Cruz, and Robert E. Schaffert, Embrapa Milho e Sorgo, Caixa Postal 151, 35 701- \\ 970, Sete Lagoas, MG, Brazil
}

\begin{abstract}
de Oliveira, E., Magalhães, P. C., Gomide, R. L., Vasconcelos, C. A., Souza, I. R. P., Oliveira, C. M., Cruz, I., and Schaffert, R. E. 2002. Growth and nutrition of mollicute-infected maize. Plant Dis. 86:945-949.

Maize bushy stunt phytoplasma (MBSP) and corn stunt spiroplasma (CSS) diseases are widespread in Brazil. The leafhopper Dalbulus maidis is the insect vector for these pathogenic mollicutes. The effects of these diseases on the development of maize plants and the possible interaction of soil water availability on these effects were evaluated in two experiments carried out on potted plants. Experiment 1 was carried out in a $2 \times 4$ factorial, where factor 1 corresponded to healthy and mollicute-infected plants and factor 2 to the maintenance of 40,60, 80, and 100\% of the total soil water availability. Leafhoppers collected from a field with high incidence of these diseases were used to inoculate plants with mollicutes. There were three treatments in experiment 2: healthy plants, plants infected with phytoplasma, and plants infected with spiroplasma. MBSP was predominant in experiment 1. The infected plants grew less and lowered nutrient uptake, in distinct proportions, indicating a differential effect of mollicutes on nutrient uptake independent of available soil water. Soil water availability did not significantly affect plant growth and nutrient uptake or mollicute infection. The results indicated that plants infected by mollicutes contained less protein than healthy plants. Experiment 2 showed a reduction in growth of plants infected with mollicutes and less nutrient uptake by spiroplasmainfected plants. The results showed a detrimental effect of the spiroplasma on Mg uptake. Both experiments showed more water retention by infected plants than by healthy ones. These experiments clearly demonstrated that reduced plant growth and nutrient uptake are major effects on plants infected with MBSP and CSS.
\end{abstract}

Maize bushy stunt phytoplasma (MBSP) and corn stunt spiroplasma (CSS) may cause severe losses in both seed and grain production of maize in Brazil $(8,13)$. The causal agents of these diseases belong to the class Mollicutes $(6,16)$. Both the phytoplasma and the spiroplasma are transmitted by leafhoppers, or in a propagative persistent manner (9). The leafhopper Dalbulus maidis is the only insect vector of these pathogens in Brazil (10).

The infection with MBSP and CSS has been associated with early plant death, proliferation of unproductive ears, and reduction in grain filling and grain weight (9). The mechanisms by which these pathogens cause disease are not well known, and the elucidation of these mechanisms may contribute to strategies for disease control.

These diseases are generally found simultaneously in the same field and sometimes on the same plant, making their dif-

Corresponding author: Elizabeth de Oliveira E-mail: beth@cnpms.embrapa.br

Accepted for publication 23 April 2002.

Publication no. D-2002-0702-01R

This article is in the public domain and not copyrightable. It may be freely reprinted with customary crediting of the source. The American Phytopathological Society, 2002. ferentiation based only on symptoms difficult. A high incidence of these diseases has been found in irrigated areas (13). Furthermore, a positive correlation among incidence levels, relative humidity, and rainfall was found in a study where maize crops were planted at monthly intervals for three consecutive years (12).

The objectives of this work were to evaluate the effects of MBSP and CSS on nutrient uptake, plant growth, and development of maize, and to investigate the possible influence of soil water availability on these effects.

\section{MATERIAL AND METHODS}

Two experiments were carried out under greenhouse conditions with protection against insects.

Experiment 1. This experiment was carried out in a $2 \times 4$ factorial; 2 inoculation treatments, infected and not infected, and 4 levels of soil water availability, 40, 60, 80, and $100 \%$. Each experimental plot consisted of two plants in a pot with $18 \mathrm{~kg}$ of soil. Each treatment was replicated six times in a completely randomized experimental design. Five seeds of the popcorn cultivar Pop Zelia were planted in each pot and inoculated with mollicutes 1 week later. Ten leafhoppers (Dalbulus maidis) collected in a popcorn field with a high incidence of MBSP and CSS were confined for 1 week under a screen cage adapted for each pot to inoculate the plants. The potted plants were then sprayed with the insecticide DDVP to eliminate the leafhoppers, the screen cages were removed, and the plants were thinned to two per pot. The different soil water levels were imposed 30 days after sowing. Soil water levels were calculated based on soil water balance obtained individually for each pot, using a digital electronic balance. The $100 \%$ treatment corresponded to field capacity. Water was supplied to return the amount of water used by the plants between watering intervals, putting the soil water back to the level of each treatment, respectively.

Experiment 2. This experiment was carried out with three treatments: healthy plants, phytoplasma-infected plants, and spiroplasma-infected plants. Each experimental plot was one pot with two plants in $20 \mathrm{~kg}$ of soil. Each treatment was replicated nine times in a completely randomized design. Five seeds of the popcorn cultivar Pop Zelia were planted in each pot and thinned to two plants per pot 1 week later. The inoculations were accomplished by confining $D$. maidis leafhoppers, either uninfected or infected by phytoplasma or spiroplasma, under screen cages (three leafhoppers per plant for 4 days). This number was determined based on previous studies (11) that found the utilization of 1 through 10 infective leafhopper specimens per plant did not alter the MBSP or CSS severity. The healthy leafhoppers were obtained from eggs isolated from maize seedling leaves and kept in petri dishes with moist filter paper until they hatched. The nymphs were then transferred to properly adapted cages for the development of the insects. The colonies were always fed with maize plants grown in the greenhouse protected from insects. Leafhoppers infected by phytoplasma or by spiroplasma were obtained by allowing healthy nymphs to feed on plants infected by only one of the pathogens during 4 days. Following this period of pathogen acquisition, the nymphs were reared in cages on healthy maize plants during a latent period of 4 weeks before inoculation. This methodology was adapted from Nault (9).

The plants in both experiments were sprayed weekly with the insecticide DDVP to eliminate nymphs coming from leafhoppers used for inoculation. The soil used in these experiments was a dark red latossol, collected under "Cerrado" vegetation, with the following chemical characteristics: 
$\mathrm{pH}_{\text {water }}$ 6.6; $\mathrm{Ca}$ and $\mathrm{Mg}$ extracted with $1 \mathrm{~N}$ $\mathrm{KCl}, 6.78$ and $0.87 \mathrm{cmol}_{\mathrm{c}} \mathrm{kg}^{-1}$, respectively; and $\mathrm{K}$ and $\mathrm{P}$ extracted by Mehlich 1, 65 and $8 \mathrm{mg} \mathrm{kg}^{-1}$, respectively (15). Fertilizer was applied before sowing in sufficient amounts to supply: $\mathrm{N}, 98 \mathrm{mg} \mathrm{kg}^{-1}$; $\mathrm{P}_{2} \mathrm{O}_{5}, 150 \mathrm{mg} \mathrm{kg}^{-1} ; \mathrm{K}_{2} \mathrm{O}, 197 \mathrm{mg} \mathrm{kg}^{-1}$; and $\mathrm{Zn}, 10 \mathrm{mg} \mathrm{kg}^{-1}$. The pots were irrigated weekly with ammonium sulfate solution to supply $\mathrm{N}$ at $20 \mathrm{mg} \mathrm{kg}^{-1}$. One of the two plants from each pot was harvested at 60 days after sowing to determine shoot dry weight and nutrient content. Shoot dry matter was determined by cutting the plants at soil level and oven drying at $75^{\circ} \mathrm{C}$ until constant weight. The plant material was ground and nutrient content was determined after digestion according to the methodology described by Sarruge and Haag (14). Nutrient uptake was calculated based upon dry matter production from each plant. The relationship between amount of water and dry matter for each plant was calculated by subtracting the value of dry matter weight from fresh weight and then dividing this result by the dry matter weight. The remaining plant was left in the pot until maturity and used to evaluate plant height, internode number, internode length, and grain production.

The occurrence of maize stunt symptoms was evaluated at 60 and 90 days after planting. One leaf from each plant was used for phytoplasma and spiroplasma detection. The phytoplasma detection was accomplished by polymerase chain reaction (PCR) assay, using specific primers for MBSP: MSB-F1 5'-AATGTCGAA CTAACAGGCGG-3' and MBS-R1 3'GGTTTTGGTTTAGGGGTT-5' and reaction conditions described by Harrison et al. (6), and also by using universal primers for phytoplasma: $\mathrm{R}_{16 \mathrm{~F}_{2}} \quad 5^{\prime}$-ACGACTGCT GCTAAGACTGG-3' and R16R 2 5'-TGA CGGGCGGTGGTACAAACCCCG-3' (7). Spiroplasma detection in experiment 1 was determined by the Western blotting test on a nitrocellulose membrane $(0.45 \mu \mathrm{m})(5)$ using polyclonal IgG anti-spiroplasma. The spiroplasma was detected in experiment 2 by PCR assay using the primers: CSSF2 5'-GGCAAAAGATGTAACAAAAGT-3' and CSSR6 5'-GTTTACTTCAACAGT AGTTGCG-3' (2). Leaf protein was measured only in experiment 1 at 60 and 90 days after sowing. Total soluble protein was evaluated by grinding $1.0 \mathrm{~g}$ of fresh leaf tissue in liquid nitrogen and diluting in a phosphate buffer ( $\mathrm{pH}$ 6.0) containing $1.5 \%$ polyvinylpyrrolidone (PVPP) (wt/vol), $1 \mathrm{mM}$ phenylmethylsulfonylfluoride (PMSF), and $1 \mathrm{M} \mathrm{NaCl}$. The homogenate was centrifuged at $14,000 \times g$ for $30 \mathrm{~min}$ at $4^{\circ} \mathrm{C}$, and the supernatant was used for quantification of protein content by the microassay method (3). The samples used were taken from the third leaf, counting from the flag leaf, and each analysis was repeated three times.

\section{RESULTS}

Mollicute-infected plants (experiment 1) showed predominantly symptoms of maize bushy stunt phytoplasma, such as tillering, proliferation of ears, stunting, and leaf reddening. However, some plants showed chlorotic leaf stripes, diagnostic of spiroplasma infection. The predominance of infection by phytoplasma compared with infection by spiroplasma was confirmed in these plants by PCR assay and by Western blotting. Phytoplasma was detected in $80 \%$ of the infected plants (data not shown).

Mollicute infection significantly reduced crop growth and grain production, independently of soil water availability (Table 1). The data also show, independent of the soil water treatments, that infected plants accumulated a greater amount of water than healthy plants. Infected plants, in general, had higher nutrient concentrations than healthy plants (Table 2); however, total nutrient content was significantly lower for these plants (Table 3). No significant effect of soil water availability on maize nutrition, growth, and grain production was detected (Tables 1 and 2).

The leaf protein content at 60 days after planting was similar between infected and healthy plants (Fig. 1), but at 90 days after

Table 1. Growth and grain production of healthy and mollicute-infected maize plants under different soil water availability (experiment 1)

\begin{tabular}{|c|c|c|c|c|c|c|c|c|c|c|}
\hline \multirow{2}{*}{$\begin{array}{l}\text { Soil water } \\
\text { availability }(\%)\end{array}$} & \multicolumn{2}{|c|}{ Plant height (cm) } & \multicolumn{2}{|c|}{ Internode $\left(\mathrm{n}^{\mathbf{0}}\right)$} & \multicolumn{2}{|c|}{ Intern. length (cm) } & \multicolumn{2}{|c|}{ Water/dry matter } & \multicolumn{2}{|c|}{ Grain weight (g) } \\
\hline & Healthy & Infected & Healthy & Infected & Healthy & Infected & Healthy & Infected & Healthy & Infected \\
\hline 40 & 176.5 & 137.5 & 12.2 & 9.6 & 13.9 & 13.5 & 3.8 & 7.7 & 80.3 & 41.9 \\
\hline 60 & 193.3 & 133.9 & 13.0 & 10.5 & 14.8 & 12.0 & 4.7 & 7.7 & 68.6 & 50.7 \\
\hline 80 & 197.4 & 141.9 & 12.5 & 10.5 & 15.6 & 13.1 & 5.3 & 7.0 & 67.0 & 55.2 \\
\hline 100 & 207.7 & 152.8 & 12.2 & 10.4 & 16.6 & 15.8 & 5.3 & 7.2 & 86.8 & 70.8 \\
\hline Averages & $193.7 \mathrm{a}^{\mathrm{z}}$ & $141.5 \mathrm{~b}$ & $12.5 \mathrm{a}$ & $10.2 \mathrm{~b}$ & $15.2 \mathrm{a}$ & $13.6 \mathrm{~b}$ & $4.8 \mathrm{~b}$ & $7.4 \mathrm{a}$ & $75.6 \mathrm{a}$ & $54.7 \mathrm{~b}$ \\
\hline $\mathrm{CV}(\%)$ & \multicolumn{2}{|c|}{18.9} & \multicolumn{2}{|c|}{18.6} & \multicolumn{2}{|c|}{9.8} & \multicolumn{2}{|c|}{25.6} & \multicolumn{2}{|c|}{40.0} \\
\hline
\end{tabular}

y $100 \%$ level of soil water availability = field capacity.

${ }^{\mathrm{z}}$ Averages followed by the same letter, on the lines for each characteristic, do not differ statistically by $F$ test $(P<0,05)$. Mean of six observations.

Table 2. Averages for nutrient concentration (\%) of healthy and mollicute infected maize plants under different soil water availability, at 60 days after sowing (experiment 1$)$

\begin{tabular}{|c|c|c|c|c|c|c|c|c|c|c|}
\hline \multirow{2}{*}{$\begin{array}{l}\text { Soil water } \\
\text { availability }^{\mathrm{y}}(\%)\end{array}$} & Healthy & Infected & Healthy & Infected & Healthy & Infected & Healthy & Infected & Healthy & Infected \\
\hline & \multicolumn{2}{|c|}{$\mathbf{N}$} & \multicolumn{2}{|c|}{$\mathbf{P}$} & \multicolumn{2}{|c|}{$\mathbf{K}$} & \multicolumn{2}{|c|}{$\mathrm{Ca}$} & \multicolumn{2}{|c|}{ Mg } \\
\hline 40 & 1.04 & 1.44 & 0.13 & 0.19 & 1.80 & 2.15 & 0.33 & 0.35 & 0.23 & 0.22 \\
\hline 60 & 1.02 & 1.52 & 0.14 & 0.17 & 1.84 & 2.37 & 0.38 & 0.38 & 0.25 & 0.25 \\
\hline 80 & 1.05 & 1.31 & 0.13 & 0.15 & 1.88 & 1.92 & 0.38 & 0.33 & 0.24 & 0.20 \\
\hline 100 & 0.98 & 1.37 & 0.13 & 0.15 & 1.86 & 2.05 & 0.34 & 0.39 & 0.22 & 0.22 \\
\hline Average & $1.02 \mathrm{a}^{\mathrm{z}}$ & $1.41 \mathrm{~b}$ & $0.13 \mathrm{a}$ & $0.16 \mathrm{~b}$ & $1.84 \mathrm{a}$ & $2.12 \mathrm{~b}$ & $0.36 \mathrm{a}$ & $0.36 \mathrm{a}$ & $0.24 \mathrm{a}$ & $0.22 \mathrm{a}$ \\
\hline \multirow[t]{2}{*}{$\mathrm{CV}(\%)$} & \multicolumn{2}{|c|}{22.7} & \multicolumn{2}{|c|}{21.2} & \multicolumn{2}{|c|}{17.4} & \multicolumn{2}{|c|}{22.1} & \multicolumn{2}{|c|}{17.1} \\
\hline & \multicolumn{2}{|c|}{$\mathbf{Z n}$} & \multicolumn{2}{|c|}{$\mathbf{F e}$} & \multicolumn{2}{|c|}{$\mathrm{Cu}$} & \multicolumn{2}{|c|}{ Mn } & \multicolumn{2}{|c|}{$\mathbf{S}$} \\
\hline 40 & 23.9 & 32.2 & 51.33 & 83.65 & 4.67 & 4.81 & 13.71 & 14.00 & 0.10 & 0.13 \\
\hline 60 & 23.0 & 33.3 & 46.96 & 52.50 & 3.50 & 4.55 & 13.71 & 16.33 & 0.10 & 0.11 \\
\hline 80 & 24.5 & 31.8 & 59.79 & 95.67 & 3.50 & 3.85 & 14.00 & 11.38 & 0.09 & 0.11 \\
\hline 100 & 22.5 & 37.9 & 49.88 & 226.63 & 2.92 & 16.92 & 11.67 & 16.63 & 0.09 & 0.12 \\
\hline Average & $23.5 \mathrm{a}$ & $33.7 \mathrm{~b}$ & $51.9 \mathrm{a}$ & $114.6 \mathrm{a}$ & $36.0 \mathrm{a}$ & $7.53 \mathrm{a}$ & $13.30 \mathrm{a}$ & $15.42 \mathrm{a}$ & $0.10 \mathrm{a}$ & $0.12 \mathrm{~b}$ \\
\hline $\mathrm{CV}(\%)$ & \multicolumn{2}{|c|}{32.1} & \multicolumn{2}{|c|}{130} & \multicolumn{2}{|c|}{204.2} & \multicolumn{2}{|c|}{33.8} & \multicolumn{2}{|c|}{15.6} \\
\hline
\end{tabular}

y $100 \%$ level of soil water availability = field capacity.

${ }^{\mathrm{z}}$ Averages followed by the same letter, on the lines for each nutrient, do not differ statistically by $F$ test $(P<0.05)$. Mean of six observations. 
planting, the protein content was greater $(P$ $<0.08)$ in mollicute-infected plants.

Spiroplasma-infected plants (experiment 2) showed typical symptoms of CSS, such as stunting and chlorotic stripes that extend toward the leaf tip. The phytoplasmainfected plants showed typical symptoms of MBSP, similar to those observed in the previous experiment. The presence of these pathogens was detected in all plants by PCR assays (data not shown).

Maize plants infected either by spiroplasma or by phytoplasma had less growth and grain production than healthy plants (Table 4). The plants infected by spiroplasma grew less than those infected by phytoplasma. Phytoplasma-infected plants, on the other hand, showed greater tillering and ear proliferation than spiroplasmainfected plants. These results show different interference of those pathogens on maize metabolic processes. The plants infected either by spiroplasma or by phytoplasma showed greater water retention than healthy plants.

With respect to nutrient concentration, only $\mathrm{N}, \mathrm{P}, \mathrm{K}$, and $\mathrm{Mg}$ showed significant differences among healthy, spiroplasmainfected, and phytoplasma-infected plants (Table 5). However, the amount of N, P, K, $\mathrm{Ca}, \mathrm{Mg}, \mathrm{S}$, and $\mathrm{Zn}$ uptake was significantly less for spiroplasma-infected plants than for healthy and phytoplasma-infected plants (Table 6).

\section{DISCUSSION}

The higher nutrient concentration observed in infected plants in experiment 1 was due to less growth and development (Tables 1 and 2). Plants with less growth generally concentrated nutrients in tissues, since they were not used for development. The reduction in total nutrient content was different for each nutrient (nitrogen 26\%, phosphorus $35 \%$, potassium $38 \%$, calcium $43 \%$, magnesium $46 \%$, zinc $23 \%$, manganese $38 \%$, and sulfur $35 \%$ ). This result suggested a differentiated interference of mollicutes on plant metabolic process and nutritional requirements. A significant effect of soil water availability on the maize nutrition, growth, and grain production was not detected. This result is possibly due to root development, the fact that in low levels of water, roots occupied all the available area in the pot and compensated for soil water availability at levels lower than $100 \%$. However, mollicute infection decreased maize nutrient uptake, growth, and grain production, being more evident at the lowest level of water availability, and increased internode length. Under rainfall conditions, the negative effects of mollicute infection on maize could be more severe.

The results indicated that plants infected by mollicutes contain less protein than healthy plants, suggesting interference in synthesis and/or translocation of protein components throughout the plant. It is possible that these diseases might affect grain nutritional quality as well as grain production, at least for some cultivars. Previous reports have indicated that the diseases caused by mollicutes affect grain production differentially, depending upon the maize cultivar infected, by reducing either grain size or grain filling (8). However, there is not much information available about seed and grain quality, either protein content (zeins, albumins) or phenotypical characteristics (vigor, specific weight, germination percentage).

The differences in nutrient concentration from infected plants in the second experiment may be the result of its lower growth (Tables 4 and 5). On the other hand, the depressed concentration of $\mathrm{Mg}$ detected in spiroplasma-infected plants (Table 5) may suggest interference of the pathogen on the uptake of this nutrient.

Spiroplasma interference, specifically on magnesium uptake, could possibly cause a reduction of photosynthesis, since this

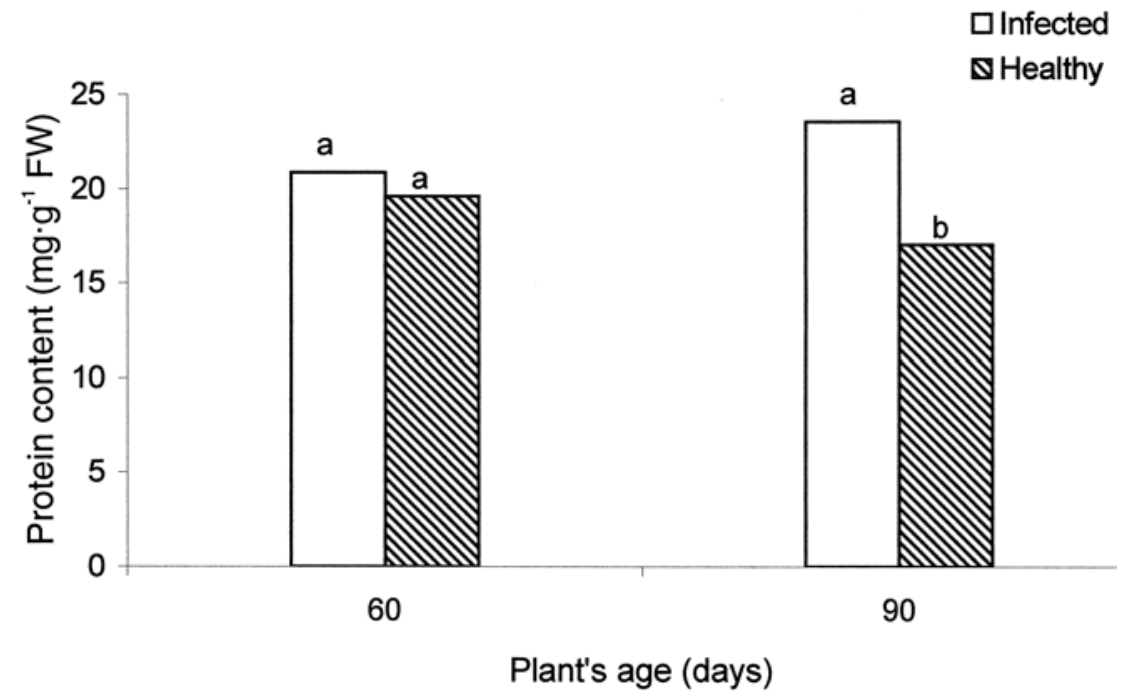

Fig. 1. Average protein content in mollicute-infected maize plants (experiment 1). Averages in a column followed by the same letter at 60 and at 90 days do not differ statistically by $F$ test $(P<$ $0.08)$. Mean of six observations.

Table 3. Averages for amount of nutrient taken up by healthy and mollicute infected maize plants, under different soil water availability, at 60 days after sowing (experiment 1$)$

\begin{tabular}{|c|c|c|c|c|c|c|c|c|c|c|}
\hline \multirow{2}{*}{$\begin{array}{l}\text { Soil water } \\
\text { availability }(\%)\end{array}$} & Healthy & Infected & Healthy & Infected & Healthy & Infected & Healthy & Infected & Healthy & Infected \\
\hline & \multicolumn{2}{|c|}{$\mathbf{N}(\mathbf{m g})$} & \multicolumn{2}{|c|}{$\mathbf{P}(\mathbf{m g})$} & \multicolumn{2}{|c|}{$\mathrm{K}(\mathrm{g})$} & \multicolumn{2}{|c|}{$\mathrm{Ca}(\mathrm{mg})$} & \multicolumn{2}{|c|}{$\operatorname{Mg}(\mathrm{mg})$} \\
\hline 40 & 683.99 & 319.94 & 84.89 & 34.61 & 1.22 & 0.48 & 212.2 & 84.9 & 155.95 & 53.72 \\
\hline 60 & 608.15 & 520.24 & 81.38 & 58.46 & 1.10 & 0.82 & 218.8 & 132.3 & 142.76 & 87.79 \\
\hline 80 & 570.72 & 527.35 & 72.36 & 60.16 & 1.07 & 0.80 & 196.7 & 131.5 & 128.36 & 85.24 \\
\hline 100 & 540.14 & 403.38 & 69.57 & 47.54 & 1.01 & 0.64 & 186.8 & 96.8 & 120.87 & 71.15 \\
\hline Average & $600.75 \mathrm{a}^{\mathrm{z}}$ & $400.73 \mathrm{~b}$ & $77.05 \mathrm{a}$ & $50.20 \mathrm{~b}$ & $1.10 \mathrm{a}$ & $0.68 \mathrm{~b}$ & $203.6 \mathrm{a}$ & $115.9 \mathrm{~b}$ & $136.99 \mathrm{a}$ & $74.48 \mathrm{~b}$ \\
\hline \multirow[t]{2}{*}{$\mathrm{CV}(\%)$} & \multicolumn{2}{|c|}{38.4} & \multicolumn{2}{|c|}{438} & \multicolumn{2}{|c|}{47.5} & \multicolumn{2}{|c|}{39.0} & \multicolumn{2}{|c|}{43.7} \\
\hline & \multicolumn{2}{|c|}{$\mathrm{Zn}(\mathbf{m g})$} & \multicolumn{2}{|c|}{$\mathrm{Fe}(\mathrm{mg})$} & \multicolumn{2}{|c|}{$\mathrm{Cu}(\mathrm{mg})$} & \multicolumn{2}{|c|}{ Mn (mg) } & \multicolumn{2}{|c|}{ S (mg) } \\
\hline 40 & 1.60 & 0.72 & 3.48 & 1.86 & 0.30 & 0.11 & 0.87 & 0.26 & 66.1 & 27.7 \\
\hline 60 & 1.38 & 1.15 & 2.81 & 1.78 & 0.20 & 0.16 & 1.15 & 0.57 & 58.7 & 39.7 \\
\hline 80 & 1.35 & 1.30 & 3.21 & 3.69 & 0.20 & 0.15 & 0.72 & 0.57 & 54.3 & 46.4 \\
\hline 100 & 1.22 & 1.10 & 2.71 & 6.88 & 0.16 & 0.44 & 0.65 & 0.44 & 51.0 & 36.2 \\
\hline Average & $1.39 \mathrm{a}$ & $1.06 \mathrm{~b}$ & 3.05 & 3.55 & 0.21 & 0.21 & $0.76 \mathrm{a}$ & $0.47 \mathrm{~b}$ & $57.5 \mathrm{a}$ & $37.5 \mathrm{~b}$ \\
\hline CV (\%) & \multicolumn{2}{|c|}{42.6} & \multicolumn{2}{|c|}{123.8} & \multicolumn{2}{|c|}{130.3} & \multicolumn{2}{|c|}{39.1} & \multicolumn{2}{|c|}{40.2} \\
\hline
\end{tabular}

y $100 \%$ level of soil water availability = field capacity.

${ }^{\mathrm{z}}$ Averages followed by the same letter, on the lines for each nutrient, do not differ statistically by $F$ test $(P<0.05)$. Mean of six observations. 
element is part of the chlorophyll molecule and an important part of all cellular metabolism. Magnesium deficiency in maize infected by the spiroplasma may also explain the development of chlorotic stripes on leaves, typical symptoms of the disease caused by this mollicute. But the mechanism by which this pathogen causes reduction in magnesium uptake is not known. Toxin production that causes growth reduction of roots has not been shown for Spiroplasma kunkelli and Spiroplasma citri (4). However, one may think that some substance from the pathogen may block magnesium uptake.

Nutrient concentrations were analyzed only in vegetative shoots. The observed differences for nitrogen and potassium concentrations between healthy and infected plants (Tables 4 and 5) suggest detrimental effects of these pathogens on uptake and/or translocation of these nutrients to reproductive parts. On the other hand, the results for phosphorus concentration show concentration effects of this nutrient proportional to plant growth.

It is most likely that the reduction in nutrient uptake is not the result of the short root growth in infected potted plants because the mobile nutrients such as nitrogen, calcium, and magnesium would be available for root uptake. Plants infected by phytoplasma had less growth and production than healthy plants (Table 4). But those plants, both healthy and phytoplasma infected, did not differ in the amount of nutrient taken up (Table 6). This suggests that the reduction in growth and grain production caused by this pathogen was due to greater tillering and ear proliferation (Table 4).

The reduction in the amount of nutrient uptake caused by spiroplasma infection was: nitrogen $39 \%$, phosphorus $36 \%$, potassium $31 \%$, calcium $40 \%$, magnesium $62 \%$, and zinc $44 \%$. Likewise, as in the previous experiment, these results suggest a differentiated effect of spiroplasma on the several plant metabolic processes and nutritional requirements.

According to Arnon (1), maize plants at the flowering stage contain around $70 \%$ of the total amount of nutrients required for growth and production. Flowering occurred around 60 days after sowing in these experiments, when the concentration and amounts of nutrient taken up were evaluated from healthy and infected plants. The results indicated that lower amounts of nutrient uptake by mollicute-infected plants may be one of the reasons for the reduction in growth and production of these plants relative to uninfected controls. The lower amount of nutrient uptake may be due to lower physiological activity of infected plants, which can be checked from the water accumulation in these plants (Tables 1 and 4). It is likely that mollicutes, being prokaryotes lacking a rigid cell wall, are very sensitive to alterations in plant cell osmotic concentration. They may have developed adaptive physiological mechanisms that result in greater water retention by the plants, and these mechanisms could result in lower physiological activity of infected plants. Such adaptative mechanisms could also influence alterations in functions such as stomatal closing and lower transpiration rates, consequently resulting in lower physiological activity of infected plants.

Among the main functions in the cellular metabolism for specific nutrients are: the role of phosphorus in energy transportation; sulfur on amino acid composition; potassium on carbohydrate transportation; and zinc as enzyme co-factor and in auxin synthesis. The actions of calcium in genetic regulation and magnesium on chlorophyll composition make it likely that reduced uptake of these nutrients will result in crop growth reduction as well. On the other hand, the results also showed possible interference of others factors, such as production alteration and equilibrium of growth substances, caused by maize mollicute action, resulting in significant reduction in plant height, tillering, and ear proliferation.

The results from these experiments confirm that mollicute infection and, more specifically, phytoplasma and spiroplasma infection have adverse effects on both plant growth and nutrient uptake of maize. The causes of this reduced metabolism can only

Table 4. Fresh weight, dry matter, and water/dry matter at flowering (60 days after planting) and plant height, number of tillers and ears, and grain weight at harvesting (110 days after planting)

\begin{tabular}{lcccccc}
\hline Treatments & $\begin{array}{c}\text { Fresh weight } \\
(\mathbf{k g})\end{array}$ & $\begin{array}{c}\text { Dry matter } \\
(\mathbf{k g})\end{array}$ & $\begin{array}{c}\text { Water/dry } \\
\text { matter }\end{array}$ & Height $(\mathbf{m})$ & Tillers $\left(\mathbf{n}^{\mathbf{o}}\right)$ & $\begin{array}{c}\text { Grain } \\
\text { Ears }\left(\mathbf{n}^{\mathbf{o}}\right)\end{array}$ \\
\hline weight $(\mathbf{g})$
\end{tabular}

${ }_{\mathrm{z}}^{\mathrm{z}}$ Averages in a column followed by the same letter, do not differ statistically by Tukey's test $(P<0.05)$. Mean of nine observations.

Table 5. Average nutrient concentration (\%) in healthy phytoplasma- and spiroplasma-infected maize plants at flowering (experiment 2)

\begin{tabular}{lccccccc}
\hline Treatments & $\mathbf{N}$ & $\mathbf{P}$ & $\mathbf{K}$ & $\mathbf{C a}$ & $\mathbf{M g}$ & $\mathbf{S}$ & $\mathbf{Z n}$ \\
\hline Healthy plants & $1.73 \mathrm{~b}^{\mathrm{z}}$ & $0.22 \mathrm{c}$ & $1.83 \mathrm{~b}$ & $0.44 \mathrm{a}$ & $0.17 \mathrm{a}$ & $0.20 \mathrm{a}$ & $24.7 \mathrm{a}$ \\
Infected by phytoplasma & $2.08 \mathrm{a}$ & $0.26 \mathrm{~b}$ & $2.18 \mathrm{ab}$ & $0.43 \mathrm{a}$ & $0.18 \mathrm{a}$ & $0.21 \mathrm{a}$ & $22.5 \mathrm{a}$ \\
Infected by spiroplasma & $2.29 \mathrm{a}$ & $0.30 \mathrm{a}$ & $2.63 \mathrm{a}$ & $0.45 \mathrm{a}$ & $0.13 \mathrm{~b}$ & $0.22 \mathrm{a}$ & $27.3 \mathrm{a}$ \\
CV (\%) & 13.9 & 13.3 & 19.9 & 36.9 & 16.7 & 17.7 & 19.4 \\
LSD & 0.33 & 0.03 & 0.52 & 0.19 & 0.03 & 0.03 & 5.68 \\
\hline
\end{tabular}

${ }^{\mathrm{z}}$ Averages in a column followed by the same letter, for each characteristic, do not differ statistically by Tukey's test $(P<0.05)$. Mean of nine observations.

Table 6. Average amount of nutrient taken up in healthy phytoplasma- and spiroplasma-infected maize plants at flowering (experiment 2)

\begin{tabular}{lccccccc}
\hline Treatments & $\mathbf{N}(\mathbf{m g})$ & $\mathbf{P}(\mathbf{m g})$ & $\mathbf{K}(\mathbf{g})$ & $\mathbf{C a}(\mathbf{m g})$ & $\mathbf{M g}(\mathbf{m g})$ & $\mathbf{S}(\mathbf{m g})$ & $\mathbf{Z n}(\mathbf{m g})$ \\
\hline Healthy plants & $2.75 \mathrm{a}^{\mathrm{z}}$ & $0.36 \mathrm{a}$ & $2.79 \mathrm{ab}$ & $0.58 \mathrm{a}$ & $0.26 \mathrm{a}$ & $0.30 \mathrm{a}$ & $3.6 \mathrm{a}$ \\
Infected by phytoplasma & $3.12 \mathrm{a}$ & $0.40 \mathrm{a}$ & $3.30 \mathrm{a}$ & $0.65 \mathrm{a}$ & $0.27 \mathrm{a}$ & $0.32 \mathrm{a}$ \\
Infected by spiroplasma & $1.67 \mathrm{~b}$ & $0.23 \mathrm{~b}$ & $1.93 \mathrm{~b}$ & $0.35 \mathrm{~b}$ & $0.10 \mathrm{~b}$ & $0.16 \mathrm{~b}$ & $2.0 \mathrm{~b}$ \\
CV (\%) & 24.8 & 23.4 & 31.4 & 31.0 & 25.9 & 23.3 & 30.7 \\
LSD & 0.71 & 0.09 & 0.99 & 0.19 & 0.06 & 0.07 & 1.09 \\
\hline
\end{tabular}

${ }^{\mathrm{z}}$ Averages in a column followed by the same letter, for each characteristic, do not differ statistically $(P<0.05)$. Mean of nine observations. 
be speculated, but it appears an alteration in nutrient balance could be an important factor, possible altering protein and auxin synthesis.

\section{LITERATURE CITED}

1. Arnon, I. 1975. Mineral nutrition of maize. International Bern. Potash Institute.

2. Barros, T. S. L., Davis, R. E., Resende, R. O., and Dally, E. L. 2001. Design of a polymerase chain reaction for specific detection of corn stunt spiroplasma. Plant Dis. 85:475-480.

3. Bradford, M. M. A. 1976. Rapid and sensitive method for the quantification of microgram of protein utilizing the principle of protein-dye binding. Anal. Biochem. 72:248-254.

4. Daniels, M. J. 1983. Mechanisms of spiroplasma pathogenicity. Annu. Rev. Phytopathol. 21:29-43.

5. Hampton, R., Balle, E., and De Boer, S., eds. 1990. Serological Methods for Detection and Identification of Viral and Bacterial Plant Pathogens - A Laboratory Manual. American Phytopathological Society, St. Paul, MN.

6. Harrison, N. A., Richardson, P. A., Tsai, J. H., Ebbert, M. A., and Kramer, J. B. 1996. PCR assay for detection of the phytoplasma associated with maize bushy stunt disease. Plant Dis. 80:263-269.

7. Lee, I.-M., Hammond, R. W., Davis, R. E., and Gundersen, D. E. 1993. Universal amplification and analysis of pathogen $16 \mathrm{~S}$ rDNA for classification and indentification of mycoplasmalike organisms. Phytopathology 83:834-842.

8. Massola-Junior, N. S., Bedendo, I. P., Amorim, L., and Lopes, J. R. S. 1999. Quantificação de danos causados pelo enfezamento vermelho e enfezamento pálido do milho em condições de campo. Fitopatol. Bras. 24:136142.

9. Nault, L. R. 1980. Maize bushy stunt and corn stunt: A comparison of disease symptoms, pathogen host ranges, and vectors. Phytopathology 70:659-662.

10. Oliveira, C. M. 1996. Variação morfológica entre populações de Dalbulus maidis (DeLong \& Wolcott, 1923) (Hemiptera: Cicadellidae) de algumas localidades do Brasil. M.S. thesis. Escola Superior de Agricultura "Luiz de Queiroz", Universidade de São Paulo, Piracicaba.

11. Oliveira, C. M., Oliveira, E., and Cruz, I.
2001. Efeito de diferentes densidades do vetor Dalbulus maidis (Hemiptera: Cicadellidae) na severidade de doenças causadas por fitoplasma e por Spiroplasma kunkelii em milho. (Abstr.) Fitopatol. Bras. 26:509.

12. Oliveira, E., and Oliveira, A. C. 2001. Incidência de Enfezamentos e de Maize Rayado Fino Virus em milho em diferentes épocas de plantio e efeito da expressão de sintomas foliares dos Enfezamentos na produção. (Abstr.) Fitopatol. Bras. 26:510.

13. Oliveira, E., Waquil, J. M., Fernandes, F. T. Paiva, E., Resende, R. O., and Kitajima, W. E. 1998. Enfezamento pálido e Enfezamento vermelho na cultura do milho no Brasil Central. Fitopatol. Bras. 23:45-47.

14. Sarruge, J. R., and Haag, H. P. 1974. Análises químicas em plantas. ESALQ, Piracicaba.

15. Vettori, L. 1969. Métodos da análise do solo. EPE, Rio de Janeiro: Boletim Técnico, 7.

16. Whitcomb, R. F., Chen, T. A., Wlliamson, D L., Liao, C., Tully, J. G., Bové, J. M., Mouch ES, C., Rose, D. L., Coan, M. E., and Clark, T. B. 1986. Spiroplasma kunkelii sp. Nov., characterization of the etiological agent of corn stunt disease. Int. J. Syst. Bacteriol. 36:170-178. 